\title{
Analisis Sistem Jalur Terpendek Menggunakan Algoritma Djikstra dan Evaluasi Usability
}

\author{
Yulvia Nora Marlim¹, Deny Jollyta ${ }^{\# 2}$, Fandri Saputra*3 \\ ${ }^{\#}$ Teknik Informatika, Sekolah Tinggi Ilmu Komputer Pelita Indonesia \\ Jalan Ahmad Yani No 78-88 \\ ${ }^{1}$ yulvia.noraelecturer.pelitaindonesia.ac.id \\ 2deny.jollytallecturer.pelitaindonesia.ac.id \\ *Sistem Informasi, Sekolah Tinggi Ilmu Komputer Pelita Indonesia \\ Jalan Ahmad Yani No 78-88 \\ ${ }^{3}$ fandri.saputra@student.pelitaindonesia.ac.id
}

\begin{abstract}
Abstrak - Tingginya motivasi masyarakat pengguna kendaraan roda empat pribadi, menyebabkan semakin meningkat pula kebutuhan terhadap bengkel mobil. Usaha bengkel ini tumbuh dan berkembang pada titik-titik strategis hamper di semua kota-kotabesar di Indonesia. seperti Pekanbaru yang memiliki luas $\pm 632.26 \mathrm{~km}^{2}$. Akibatnya timbul kesulitan dalam mengetahui letak/ alamat bengkel yang hendak dituju secara cepat dari posisi terdekat. Penelitian ini bertujuan utuk menentukan jalur terpendek menuju lokasi bengkel mobil menggunakan algoritma Djikstra melalui aplikasi berbasis web. Hal ini dapat mempermudah masyarakat ketika mengalami kerusakan mobil dimanapun. Algoritma Djikstra bekerja menggunakan graph dengan prinsip greedy yaitu mencari nilai minimum setiap simpul yang dilalui dengan teknik penelusuran mengunakan Best Fisrt Search (BFS). BFS yaitu dengan menelusuri simpul yang tertinggi (awal) kemudian penelusuran ke simpul dibawahnya. Aplikasi selanjutnya diuji dengan evaluasi usability. 5 komponen usability yang digunakan adalah learnability, effesiency, memorability, error, dan saticfaction yang disusun menggunakan kuisoner. Respondennya terdiri dari masyarakat umum yang dipilih secara acak yang terdiri dari 30 responden. Uji usability menggunakan skala likert yang terdiri dari 14 pertanyaan, dengan teknik perhitunggan menggunakan rata-rata sederhana. Hasil dari pengujian menunjukan bahwa nilai usability dari aplikasi jalur terpendek adalah $78,5 \%$, hal ini menujukan bahwa aplikasi jalur terpendek bernilai baik. Artinya bahwa responden merasa puas dengan adanya aplikasi ini dan terbantu dalam menentukan bengkel terdekat.
\end{abstract}

Kata kunci - Jalur Terpendek, Algoritma Djikstra, Usability, Best Firsh Search (BFS).

\section{PENDAHULUAN}

Seiring dengan tingginya tingkat kebutuhan masyarakat terhadap kendaraan pribadi, sehingga meningkat juga kebutuhan terhadap bengkel mobil. Jika mobil mereka mengalami kerusakan, mereka akan mencari bengkel mobil yang sesuai dengan kebutuhan, dan tentunya sebagian besar dari masyarakat ingin cepat sampai ke tujuan dengan memilih alternative jalan terdekat atau jalan pintas. Dengan alasan untuk menghemat waktu, biaya (bahan bakar) dan tenaga

Luas wilayah kota Pekanbaru adalah 632,26 KMㄹ. Dengan luas tersebut masyarakat kesulitan mencari lokasi / alamat bengkel yang dicari secara cepat. Berdasarkan wawancara dari salah satu pegawai SAMSAT kota Pekanbaru. Setiap tahun pembelian mobil baru, Rata-rata peningkatannya kurang lebih $13 \%$ - $15 \%$, dilihat dari penerbitan STNK dan BPKB baru.

Data yang diambil adalah bengkel mobil dalam skala menengah ke atas. Peneliti juga melakukan observasi ke lapangan dengan mewawancarai calon konsumen umum dan pemilik bengkel. Hasil dari wawancara tersebut dapat ditarik kesimpulan bahwa calon konsumen mengalami kesulitan untuk mengetahui alamat bengkel mobil yang mereka inginkan walaupun sudah ada kartu nama. Disebabkan sebagian besar calon konsumen kurang mengetahui rute-rute dikota Pekanbaru, serta dikota Pekanbaru banyak jalan persimpangan dan jalan tikus (jalan kecil) dan juga terdapat beberapa lokasi bengkel masuk kedalam dan jauh dari jalan besar. Apalagi untuk masyarakat yang baru berkunjung ke kota Pekanbaru. Terkadang calon konsumen sering berhenti dijalan untuk menanyakan alamat ke penduduk sekitar, oleh sebab itu calon konsumen memerlukan biaya tambahan dan waktu tambahan untuk mencari lokasi bengkel yang dituju.

Dalam mencari lokasi bengkel menggunakan metode algoritma djikstra untuk menentukan rute terpendek. Algoritma djikstra merupakan salah satu algoritma greedy dengan bobot terendah [1]. Algoritma djikstra merupakan salah satu bentuk algoritma yang banyak digunakan dalam menentukan rute terdekat [2]. Prinsipnya adalah mencari dua atau lebih lintasan dengan nilai bobot terkecil [3]. Syaratnya adalah bobotnya harus bernilai positif. jika 
bobotnya bernilai negatif maka proses perhitungannya tidak bisa di lakukan. Penelitian yang dilakukan oleh [4] tentang pencarian SPBU terdekat menjelaskan bahwa algoritma djikstra merekomendasikan jarak tempuh terdekat untuk menghemat penggunaan bahan bakar kendaraan.

Melihat kebutuhan dari pengunjung yang menginginkan sebuah sistem mempunyai user interface. Maka aplikasi jalur terpendek ini akan diuji. Pengujiannnya berdasarkan human computer interaction (interaksi manusia dan computer). Human Computer Interaction memiliki prinsip usability ada 3 syarat untuk memenuhi prinsip usability, yaitu sistem itu harus useful yaitu website sesuai dengan kebutuhan pengunjung, usable yaitu mudah dipelajari dan digunakan [5]. User Freindly yaitu sistem ini mempunyai tampilan yang menarik, dan pengunujung senang dan nyaman menggunakannya sehingga nantinya sistem ini banyak diakses oleh pengujung. Dengan kata lain prinsip usability atau pendayagunaan ini juga berhubungan dengan tingkat kepuasan pengujung [6]. Usability juga mengacu kepada bagaimana user memahami dan menggunakan produk untuk memperoleh tujuan dan menilai tingkat kepuasan dari pengguna [7]. Penilaian dari usability oleh pengunjung akan menjadi evaluasi untuk memperbaiki atau mengembangkan sistem menjadi lebih baik. Komponen usability yang digunakan pada penelitian ini adalah learnability, effeciensci, memorability, error, dan saticfation.

Berdasarkan uraian permasalahan diatas, dibutuhkanlah sebuah sistem informasi yang akan menjadi petunjuk jalan bagi pengunjung dengan menampilkan rute terpendek ketempat bengkel yang dituju. Diharapkan sistem yang dibuat memiliki prinsip usability yang sesuai dengan kebutuhan pengunjung. Diharapkan dengan adanya sistem informasi pencarian bengkel mobil dengan rute terpendek dapat membantuk calon konsumen/pengunjung cepat sampai di tempat tujuan dan menghemat waktu, biaya, dan tenaga.

\section{PERANCANGAN SisteM}

Pada penelitian ini metode penelitian gambarkan dalam bentuk kerangka penelitian. Dapat dilihat pada gambar 1 yang tediri dari 5 tahap yaitu 1) Identifikasi kebutuhan, 2) Analisa data, 3) pelaksanaan, 4) Pengolahan data, 5) Implementasi, 6) Pengujian.

Pada tahap identifikasi kebutuhan langkah yang diterapan adalah dengan terun langsung kelapangan. Mewawancari beberapa masyarakat dan pemilik bengkel. Kemudian merumuskan masalah yang didapat dari hasil wawancara. Serta menentukan tujuan dari penelitian.

Analisa data, pertama mengumpulkan studi literatur dengan cara mencari beberapa referensi baik itu berupa artikel, buku, majalah maupun artikel ilmiah. Kemudian dilakukan pengumpulkan data, yaitu data bengkel di kota Pekanbaru dan menentukan titik koordinat (Latitude dan
Longitude) sebanyak 20 bengkel. Berikut titik koordinat bengkel dapat dilihat pada tabel 1 .

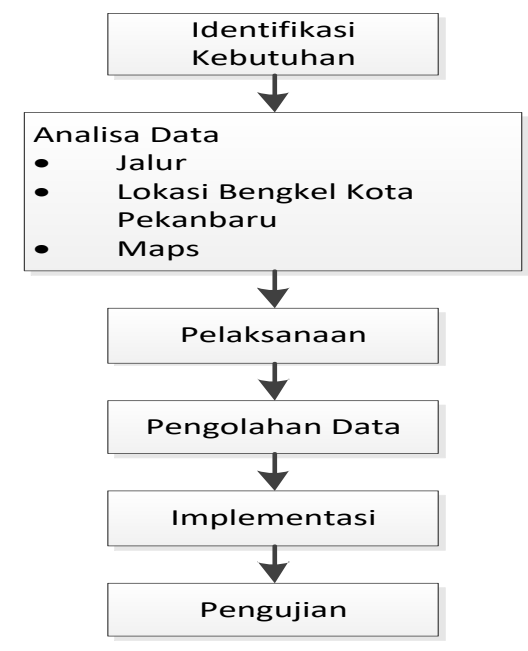

Gambar. 1 Kerangka penelitian

TABEL I

TITIK KOORDINAT BENGKEL

\begin{tabular}{|l|l|l|}
\hline \multicolumn{1}{|c|}{ Bengkel } & \multicolumn{1}{|c|}{ Latitude } & Longitude \\
\hline B1 & 0.484655 & 101.394401 \\
\hline B2 & 0.482272 & 101.415623 \\
\hline B3 & 0.474658 & 101.424192 \\
\hline B 4 & 0.490201 & 101.418129 \\
\hline B5 & 0.496981 & 101.418730 \\
\hline B $\ldots$ & $\ldots \ldots \ldots \ldots$ & $\ldots \ldots \ldots \ldots$ \\
\hline B $\ldots$ & $\ldots \ldots \ldots \ldots$ & $\ldots \ldots \ldots \ldots$ \\
\hline B20 & 0.494729 & 101.496617 \\
& & \\
\hline
\end{tabular}

Pengolahan Data dan perancangan sistem. Data yang didapat lalu diolah dan dilakukan perhitungannya dengan menggunakan algoritma djikstra. Yang kemudian dirancang sebuah sistem untuk diimplementasikan. Kemudian dilakukan tahap pengujian. Pengujian sistem menggunakan evaluasi usability, dengan cara menyebarkan angket ke 30 orang responden, yang terdiri dari pegawai negeri sipil, ibu rumah tangga, mahasiswa, karyawan swasta.dan sopir

\section{A. Jalur Terpendek}

Jalur terpendek adalah lintasan yang dilalui dari simpul awal ke simpul tujuan dengan jalur terdekat dan tercepat, untuk mencari jalur tependek menggunakan graph. Bobotnya diambil berdasarkan jarak tempuh dan waktu tempuh atau disebut weighted graph [8]. Bobot pada graph merupakan jarak yang ditempuh, untuk menentukan jalur tependek menuju bengkel mobil. Untuk menentukan jalur terpendek menggunakan algoritma djikstra dimana bobot yang digunakan hanya yang bernilai positif, jika bobotnya bernilai negatif maka tidak bisa.

\section{B. Algoritma Djikstra}

Algoritma ini merupakan salah satu dari banyak algoritma yang banyak digunakan untuk memecahkan 
permasalahan optimasi yang sering juga disebut sebagai algoritma greedy [1].Cara yang diterapkan pada algoritma ini adalah untuk memecahkan permasalahan jalur terpendek adalah dengan mencari nilai atau bobot minimum dapat setiap node dalam sebuah graph [2]. Algoritma djikstra dalam bentuk graph. Pada gambar 2 dapat dilihat contoh dari graph algoritma djikstra. Pada gambar 2 merupakan contoh kasus dimana simpul a merupakan simpul awal atau bisa diilustrasikan sebagai alamt awal dan simpul f merupakan simpul alamat atau tujuan. Untuk mengetahui jalur/rute terpendek dari simpul a menuju $f$ maka dicari bobot dengan nilai terkecil menggunakan algoritma djikstra. Lebih lengkapnya tahapan dari algoritma djikstra yang dilakukan adalah [1].

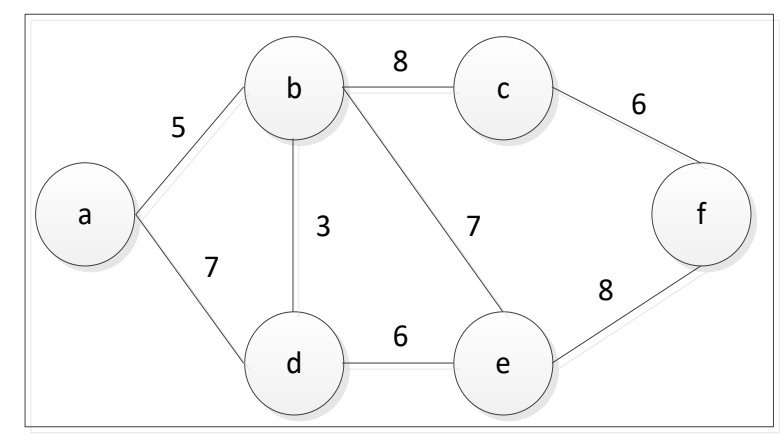

Gambar. 2 Graph algoritma djikstra

Langkah pertama tentukan simpul awal atau sumber dan simpul tujuan. Gambar 2 terlihat simpul awal adalah a dan simpul tujuan adalah f. Kedua beri bobot (nilai) untuk semua simpul, cara menentukan bobot berdasarkan jarak tempuh antara simpul. Simpul awal bobotnya 0 . Selanjutnya langka ketiga dari simpul awal yaitu simpul a, di lihat simpul yang terhubung dengan a adalah simpul $b$ dan d, dari simpul b dan d, dilihat bobot yang bernilai terkecil, yaitu a-b bernilai 5. Tahap keempat tetapkan bahwa simpul (b) terpilih, dan pada simpul yang dipilih (b) dapat dilihat ada node yang terbuhung yaitu d dan $\mathrm{c}$, , ab-c bernilai $5+8=13$, a-b-d bernilai $5+3=8$, a-b-e bernilai $5+7=12$, dari hasil yang didapat, terlihat nilai terkecil dilalui oleh simpul a-b-d bernilai 8. Selanjutnya lakukan hal yang sama sehingga simpul akhir atau tujuan di temukan.

Penelusuran sirkuit dari algoritma djikstra dilakukan dengan teknik Best First Search (BFS). Teknik BFS dilakukan dengan menelusuri titik (simpul) awal. Dikarenakan simpul awal terletak pada tingkat tertinggi kemudian penelusuran akan dilakukan ke titik (simpul) dibawahnya [8]. Best First Search merupakan kombinaasi dari teknik Depth First Search dan Breadth First Search [9]. Pada algoritma djikstra titik (simpul) yang akan ditelusuri adalah simpul yang memiliki bobot terkecil [1].

\section{Sistem Informasi Geografis (SIG)}

SIG dapat membantu dalam mengambilan keputusan, karena SIG lebih mudah dan cepat dalam mengolah data spasial [10]. SIG banyak digunakan dalam mentukan masalah-masalah jalur terpendek yang dikolaborasi dengan algoritma djikstra, beberapa contohnya masalah menemukan objek wisata, peta rumah sakit, dan jalur-jalur untuk angkutan umum trans metro [11]. Sistem informasi geografis dapat mengatasi masalah-masalah [12]. Pertama memberikan ilustrasi dengan melakukan komputasi. Kedua menenentukan tempat tertentu yang akan dituju. Dan Ketiga data dan informasi diorganisasikan.

\section{Rekayasa Kebutuhan Fungsional}

Kebutuhan fungsional adalah layanan-layanan yang harus disediakan oleh sistem untuk memenuhi kebutuhan dari user. Kebutuhan fungsional menggunakan use case diagram [2]. Dilihat pada gambar 3. Pada gambar 3 merupakan bentuk use case diagram dari Aplikasi jalur/rute terpendek. Use case adalah menggambarkan dinteraksi beberapa aktor didalam sebuah sistem. Case tergambarkan didalam use case. Dapat dijelaskan pada gambar 2 use case sistem hanya di gunakan atau dipakai oleh 2 user yaitu admin dan pengunjung. Admin bertugas untuk mengupdate informasi tentang bengkel. Pengunjung dapat melihat informasi tentang bengkel berupa alamat bengkel, jasa-jasa yang disediakan, bengkel yang terdekat dengan pengujung serta informasi rute atau jalur terpendek menuju bengkel yang diinginkan.

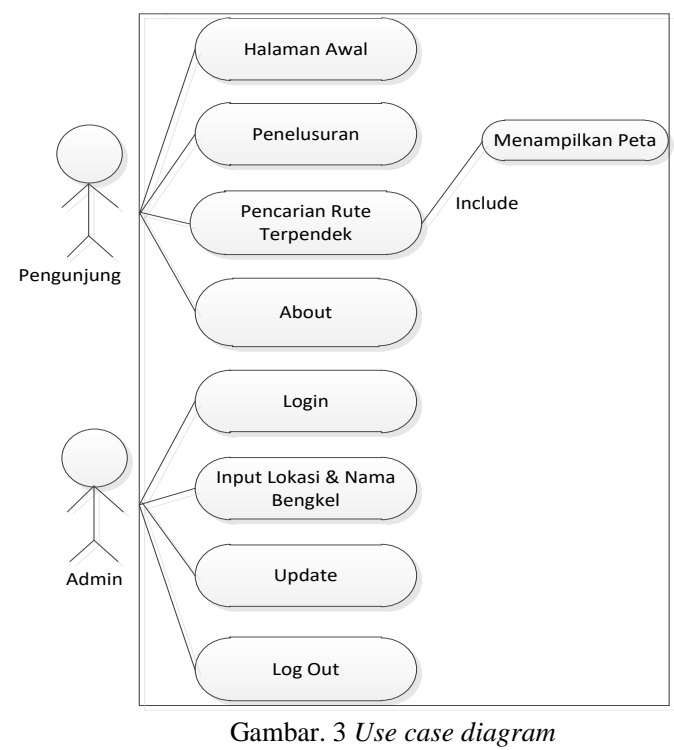

\section{E. Rekaya Kebutuhan Non Fungsional}

Kebutuhan non fungsional adalah keterbatasan yang dimiliki oleh sistem. Pada penelitian ini kebutuhan non fungsional yang di teliti adalah usability. Usability merupakan analisa kualitatif yang dugunakan untuk menentukan kepuasan dai pemakai, Usability maksudnya agar sistem yang di gunakan dapat dipakai dengan baik. Pengujian usability dilakukan sebelum website ini di 
terapkan secara online. usability terdiri dari 5 komponen dapat dilihat pada gambar 4.

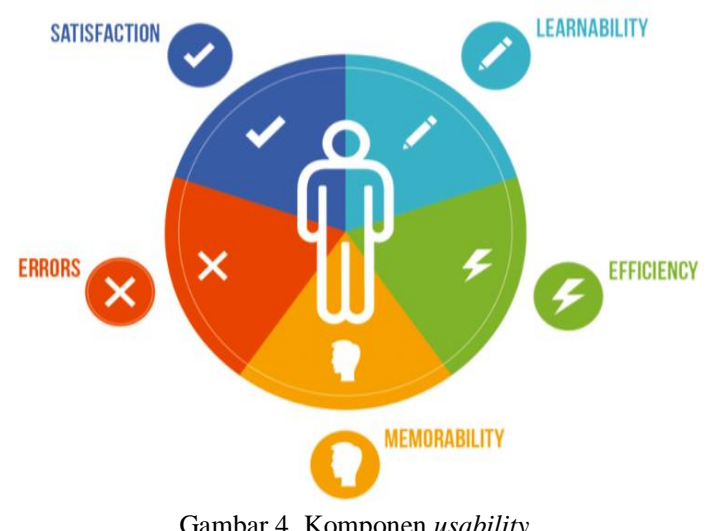

III. HASIL DAN PEMBAHASAN

Komponen usability yang digunakan adalah pertama learnability maksudnya sistem mudah dioperasikan dan dipahami. Kedua memorability adalah sistem mudah dipelajari, sehingga jika tidak gunakan dalam jangka lama, user masih bisa dengan mudah mengoperasikan. Ketiga efficiency merujuk kepada seberapa cepat sistem dapat membantu user. Keempat error maksudnya sistem memiliki tingkat error minimal. Kelima saticfation maksudnya user puas menggunakannya dan merasa terbantu dengan adanya sistem ini.

\section{A. Analisa Dengan Algoritma Djikstra}

Gambar 5 adalah contoh kasus analisis algoritma djikstra dalam bentuk graph. Contoh kasus yang diambil dari Jalan Ahmad Yani No 78 menuju bengkel Mobil 3 R Jala SM. Amin Pekanbaru sehingga didapatlah bentuk graph seperti gambar 5 .

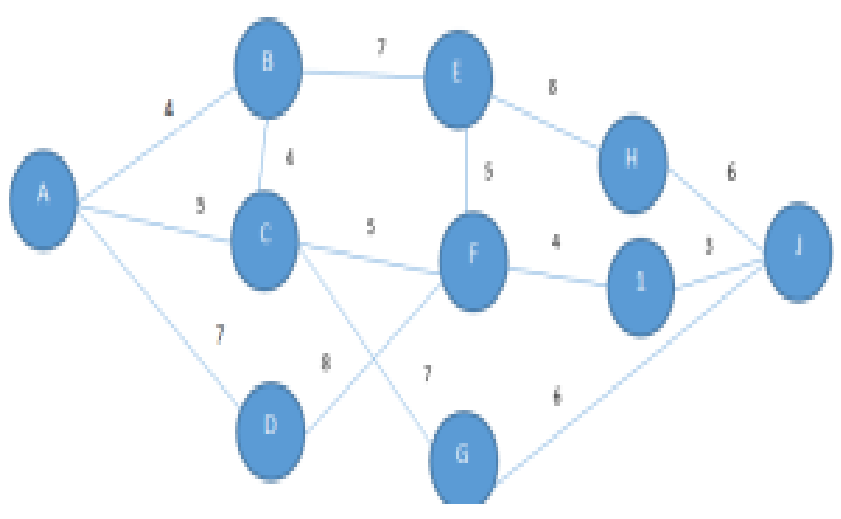

Gambar 5. Graph menuju bengkel $3 \mathrm{R}$

Keterangan :
1). Jalan Ahmad Yani
2). Jalan Sudirman
3). Jalan Nangka
4). Jalan Jendral
5). Jalan Arifin Ahmad
6). Jalan Soekarno Hatta
7). Jalan Nangka Ujung
8). Jalan Hr Soebrantas
9). Jalan Rajawali Sakti
10). Jalan SM Amin Bengkel 3 R

Simpul A merupakan titik awal keberangkatan yaitu dari jalan Ahmad Yani menuju simpul J, yaitu simpul tujuan bengkel 3R Pekanbaru jalan SM Amin no 77. Kemudian beri bobot untuk semua simpul, untuk simpul awal yaitu A bobot dinilai dengan 0. Langkah selanjutnya dari simpul awal keberangkatan simpul A yang terhubung yaitu simpul B, C, D dari ketiga simpul yang dipilih jumlah bobot terkecil yaitu A-B dengan bobot $0+4=4$. Ditetapkan simpul B yang terpilih. Selanjutnya dilihat simpul yang terhubung dengan simpul $\mathrm{B}$ yaitu simpul $\mathrm{C}$ dan $\mathrm{E}$, dan pilih bobot yang terkicil $\mathrm{A}-\mathrm{B}-\mathrm{C}=0+4+4=8$, $\mathrm{A}-$ $\mathrm{B}-\mathrm{E}=0+4+7=11$, maka ditetap simpul A-B-C yang terpilih dengan nilai 8 , kemudian lakukan langkah yang sama, untuk menuju simpul A ke J yang dilalui adalah simpul AB-C-F-I-J $=0+4+4+5+4+3=20$. Cara pehitungan ini berlaku untuk semua jalur menuju bengkel mobil.sampai simpul tujuan didapati. Dari langkah diatas maka didapat hasil untuk menuju simpul A ke J yang dilalui adalah simpul A-B-C-F-I-J $=0+4+4+5+4+3=20$. Cara pehitungan ini berlaku untuk semua jalur menuju bengkel mobil.

\section{B. Gambaran Umum Aplikasi}

Gambar 6 merupakan gambaran umum dari sistem jalur terpendek. Pada gambar 6 dapat dilihat dimana pengujung dapat mengetahui informasi tentang bengkel dan informasi rute atau jalur terpendek menuju jasa bengkel yang Pengunjung inginkan dan bengkel yang terdekat dengan posisi pengunjung. Admin bertugas megelola data data bengkel.

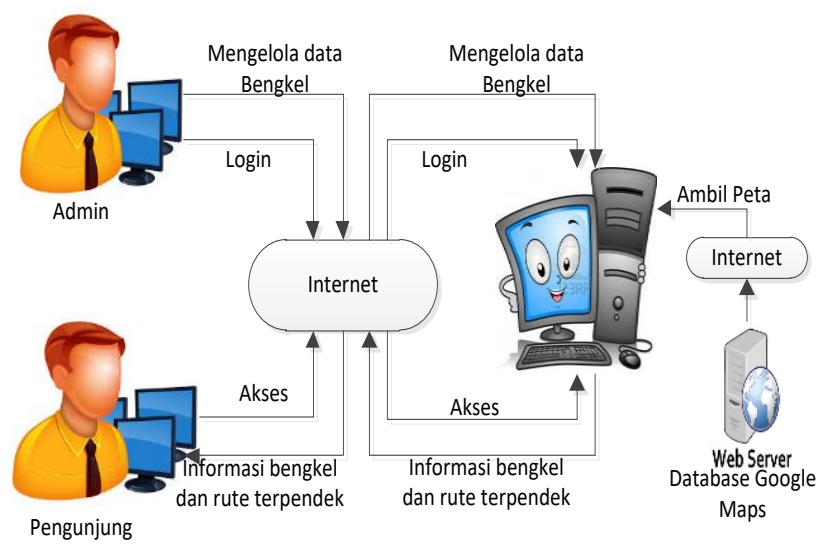

Gambar. 6 Diagram arsitektur 


\section{Implementasi Halaman Utama}

Pada halaman utama terdiri dari home, dan sistem pencarian, serta informasi tentang bengkel dapat dilihat pada gambar 7 berikut.

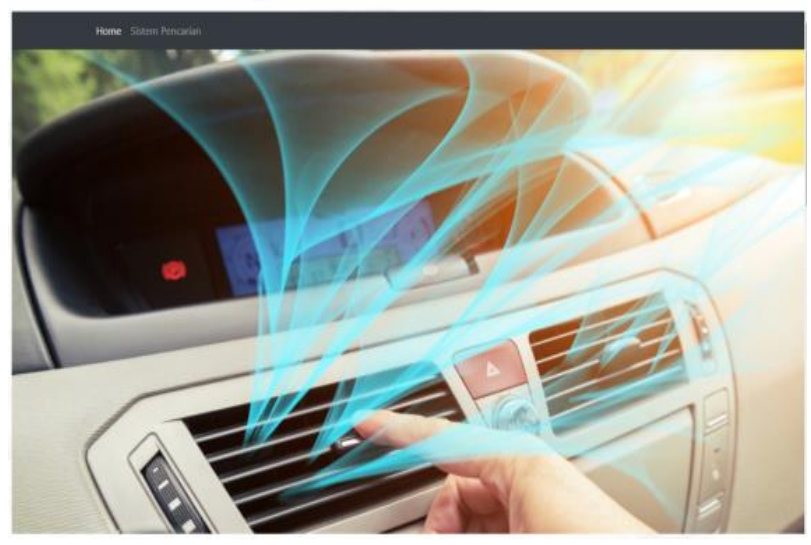

Gambar. 7 Halaman utama

\section{Implementasi Halaman Sistem Pencarian}

Pada implementasi halaman sistem pencarian terdapat menu rute dan info bengkel. Dapat dilihat pada gambar 8 .

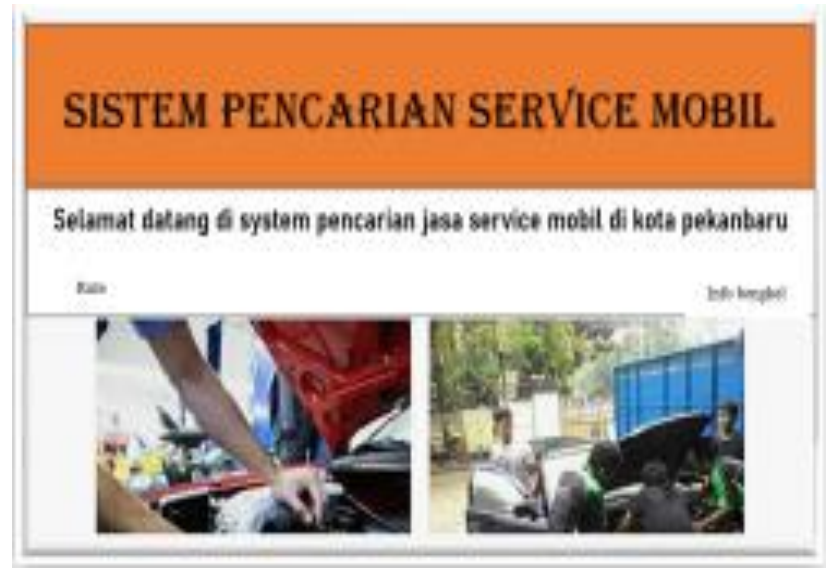

Gambar. 8 Halaman sistem pencarian

\section{E. Implementasi Halaman Penelusuran}

Implementasi pada halam jalur dapat dilihat pada gambar 9 yang menampilkan jalur/rute menuju bengkel, dengan menuliskan tujuan/alamat bengkel. Yang dapat dilihat pada gambar 9 dibawah ini.

\section{F. Pengujian Usability}

Usability adalah pengujian yang dilakukan untuk mengetahui seberapa mudah sistem di operasikan [13]. Pada penelitian [14] tingkat efisiensi dan dan efektifitas usability diukur menggunakan user's succsess rate atau tingkat keberhasilan pengguna ditentukan presentasi tugas yang benar oleh pengguna. Pengujian ini dilakukan dengan cara menyebarkan angket ke respoden. Responden terdiri dari masyarakat umum dipilih secara acak yang berpropersi sebagai supir, karyawan swasta, ibu rumah tangga, pegawai negri sipil. Pertanyaan yang berikan disesuai dengan kebutuhan usability yaitu, berdasarkan learnability, memoribility, efficiency, error, dan saticfation. Penyebaran angket diberikan untuk 30 orang responden. Kuisoner yang di sebarkan dalam bentuk skala likert. Dilihat pada table 2, tabel 2 merupakan interval dari pengujian usability dengan menggunakan skala likert.

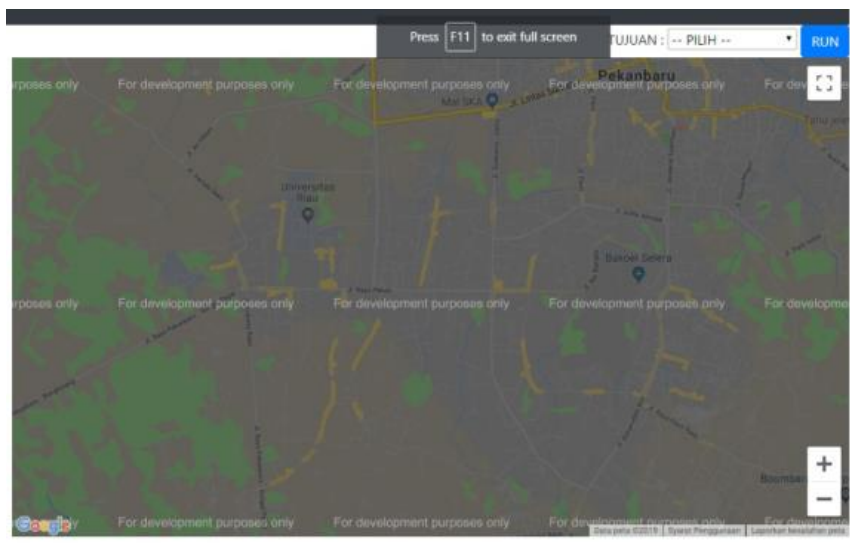

Gambar. 9 Halaman penelusuran

TABEL III

INTERVAL SKALA LIKERT

\begin{tabular}{|l|l|}
\hline Sangat tidak setuju & 1 \\
\hline Kurang Setuju & 2 \\
\hline Cukup Setuju & 3 \\
\hline Baik & 4 \\
\hline Sangat Baik & 5 \\
\hline
\end{tabular}

Kuisoner terdiri dari 14 pertanyaan. Sebelum mengisi kuisoner, responden terlebih dahulu disuruh mencoba website. Sesuai dengan panduan, kemudian dipersilahkan untuk mengisi kuisoner.

Kuisoner yang telah diisi, dikumpulkan datanya, kemudian dilakukan pengolahan data. Dengan cara sederhana yaitu menghitung rata-rata pada setiap komponen di usability. Yaitu learnability, efficiency, memorability, error, dan saticfation. Pada komponen error Pertanyaan berupa pertanyaan negarif yang artinya setiap skor yang diisikan nantinya merupakan kebalikannya. Langkah pertama menggunakan rumus (1). Rumus (1) digunakan untuk menentukan nilai awal pada setiap komponen usability

$$
\text { Rumus }=P n / T
$$

$\mathrm{T}=$ Jumlah Responden

Pn $=$ Skor Skala Likert

Sehingga didapat hasil seperti tabel 3. Tabel 3 adalah nilai awal usability per komponen yang didapat dari total skor angket yang diisi oleh responden dibagi jumlah responden. 
TABEL IIIII

NILAI AWAL USABILITY PER KOMPONEN

\begin{tabular}{|l|l|}
\hline Usability & Nilai \\
\hline Learnability & 4.08 \\
\hline Effeciency & 4.18 \\
\hline Memorability & 4.17 \\
\hline Error & 4.22 \\
\hline Saticfaction & 4.03 \\
\hline
\end{tabular}

Selanjutnya mencari nilai persentase untuk masing masing komponen usability menggunakan rumus (2).

$$
\text { KomponenUsability }=\frac{\text { JumlahSkor }}{\text { SkorMaksimum }} * 100 \%
$$

Pada rumus (2) jumlah skor didapat dari jumlah skor yang diisi oleh semua responden pada setiap pertanyaan, misalnya pada pertanyaan pertama, skor 5 diisi oleh 5 responden, skor 4 diisi oleh 15 responden, skor 3 diisi oleh 8 responden dan skor 2 diisi oleh 2 responden.jika dibuat dalam bentuk table dapat dilihat pada tabel 4 .

\section{TABEL IVV}

JUMLAH SKOR

\begin{tabular}{|c|l|}
\hline Skala Likert & Jumlah responden \\
\hline 5 & 5 \\
\hline 4 & 15 \\
\hline 3 & 8 \\
\hline 2 & 2 \\
\hline 1 & 0 \\
\hline
\end{tabular}

Untuk mencari skor maksimum didapat dari jumlah responden dikali skor tertinggi yaitu $30 * 5=150$

Sehingga dengan menggunakan rumus (2) untuk mencari nilai persentase didapatlah hasil dapat dilihat pada tabel V. Tabel V merupakan nilai tiap komponen usability dalam bentuk persentae.

TABEL V

PERSENTASE USABILITY

\begin{tabular}{|l|l|}
\hline Komponen & Persentase \\
\hline Learnability & $77,3 \%$ \\
\hline Effeciency & $74,7 \%$ \\
\hline Memorability & $82 \%$ \\
\hline Error & $77,8 \%$ \\
\hline Saticfaction & $80,9 \%$ \\
\hline
\end{tabular}

Pada Tabel 5 dijelaskan bahwa learnability memiliki persentae 77, 3\%, effeciency 74,7\%, memorability $82 \%$ error $77,8 \%$ dan saticfaction $80,9 \%$. Dapat diartikan bahwa nilai perkomopnen usability diatas bernilai >=baik. Setelah hasil perkomponen usability didapat, yang kemudian diukur tingkat penilaian usability perkomponen berdasarkan skala likert dengan pembagian persentase maksimal $100 \%$ [15]. Dilihat pada tabel VI. Tabel VI merupakan tabel interval persentase penilaian.

TABEL VV

INTERVAL PERSENTASE PENILAIAN

\begin{tabular}{|l|l|}
\hline Persentase & Penilaian \\
\hline $81 \%-100 \%$ & Sangat Baik \\
\hline $61 \%-80 \%$ & Baik \\
\hline $41 \%-60 \%$ & Cukup \\
\hline $21 \%-40 \%$ & Kurang Baik \\
\hline $0 \%-20 \%$ & Sangat Kurang Baik \\
\hline
\end{tabular}

Setelah didapat hasil presentase masing-masing komponen. Langkah selanjutnya adalah mencari nilai usability dari aplikasi jalur terpendek dengan menggunakam rumus (3). Dilihat pada rumus (3) untuk mencari nilai persentase usability dari aplikasi jalur terpendek ini yaitu dengan menjumlahkan nilai semua komponen dibagi total komponen.

$$
\text { Usability\% }=\frac{\text { TotalPersentaseKomponen }}{5}
$$

Sehingga dengan menggunakan rumus (3), maka didapat nilai akhir dari usability website pencarian bengkel mobil dengan jalur terpendek adalah 78, $5 \%$. Di lihat dari tabel 6 persentase usability menggunakan skala likert maka 78,5 dikategorikan dengan penilaian baik.

\section{KESIMPULAN}

Pada penelitian ini algoritma djikstra dapat diterapkan pada website pencarian rute terpendek yang mudah diakses dan digunakan oleh pengguna. Keunggulan dari sistem ini dapat terlihat dari pengujian non fungsional usability yang melibatkan 5 komponen, yaitu learnability dengan nilai 77, $3 \%$ kategori penilaian baik, Effeciency dengan nilai 74,7 \% dengan peneliaan baik. Memorability persentase $82 \%$ dengan kategori penilaian sangat baik. Error 77,8 \% dengan kategori penilaian baik. Dan Saticfaction dengan nilai persentase $80,9 \%$. Dapat disimpulkan bahwa nilai usability yang diuji dengan 30 responden, untuk seluruh komponen adalah 78,5 \%, artinya adalah bahwa website pencarian bengkel mobil dengan rute terpendek dengan nilai baik. Dengan intervail $61 \%$ - $80 \%$. Sehingga dapat dikatakan bahwa website ini user friendly yaitu pengunjung merasa senang menggunakannya, useful yaitu website ini bermanfaat untuk yang menggunakan dan useble artinya mudah dipelajari. 


\section{UCAPAN TERIMA KASIH}

Terima Kasih penulis ucapkan kepada pihak Institut Bisnis dan Teknologi Pelita Indonesia yanag telah memberikan dana untuk publikasi artikel ini.

\section{REFERENSI}

[1] D. Ardana and R. Saputra, "Penerapan Algoritma Dijkstra pada Aplikasi Pencarian Rute Bus Trans Semarang," no. Snik, pp. 299306, 2016.

[2] D. A. Syamsuddin, muhammad yusuf, Musliman Hanifah A, Harnoni, "Implementasi Algoritma Dijkstra Dalam Menemukan Jarak Terdekat Dari Lokasi Pengguna Ke Tanaman Yang Di Tuju Berbasis Android ( Studi Kasus di Kebun Raya Purwodadi ),” vol. 1, no. August, 2017.

[3] D. T. Salaki, "Penentuan Lintasan Terpendek Dari Fmipa Ke Rektorat Dan Fakultas Lain Di Unsrat Manado Menggunakan Algoritma Djikstra," J. Ilm. Sains, vol. 11, no. 1, p. 73, 2011.

[4] R. A. Eka, yulia windi, Istiadi Dwiretno, "Pencarian SPBU Terdekat dan Penentuan Jarak Terpendek Menggunkan Algoritma Dijkstra (Studi Kasus di Kabupaten Jember)," Nas. Tek. Elektro, vol. 4, no. 1, pp. 89-93, 2015.

[5] D. A. Sudarman, Interaksi Manusia dan Komputer. yogyakarta: Penerbiat Andi, 2007.

[6] B. R. Pudjoatmodjo, "Tes Kegunaan (Usability Testing) Pada Aplikasi Kepegawaian Dengan Menggunakan System Usability Scale (Studi Kasus : Dinas Pertanian Kabupaten Bandung),” 2016, pp. 6-7.

[7] Purwani Istiana, "Evaluasi Usability Situs Web Perpustakaan," Visi Pustaka, vol. 13, no. 3, pp. 5-10, 2011.

[8] A. Juniansyah, "Aplikasi Penentuan Rute Terpendek Untuk
Bagian Pemasaran Produk Roti Surya dengan Metode Best First Search," vol. 12, no. 1, pp. 31-40, 2016.

[9] R. Apriandi, T. Rismawan, D. M. Midyanti, and J. S. Komputer, "Penerapan Metode Best First Search (BFS) Untuk Pencarian Lokasi SPBU Terdekat Menggunakan Arduino Berbasis Android," vol. 06, no. 1, pp. 1-11, 2018.

[10] D. Manongga et al., "Sistem Informasi Geografis Untuk Perjalanan Wisata di Kota Semarang," Informatika, vol. 10, pp. 19, 2009.

[11] A. Gusmão and S. H. Pramono, "Sistem Informasi Geografis Pariwisata Berbasis Web Dan Pencarian Jalur Terpendek Dengan Algoritma Dijkstra," vol. 7, no. 2, pp. 125-130, 2013.

[12] L. J. E. Dewi, "Pencarian Rute Terpendek Tempat Wisata di Bal Dengan Menggunakan Algoritma Dijkstra," 2010, vol. 2010, no. Snati, pp. 2008-2011.

[13] D. R. Rahadi, "Pengukuran Usability Sistem Menggunakan Use Questionnaire Pada Aplikasi Android,” vol. 6, no. 1, pp. 661-671, 2014.

[14] Y. Nurhadryani, S. K. Sianturi, I. Hermadi, and H. Khotimah, "Pengujian Usability untuk Meningkatkan Antarmuka Aplikasi Mobile," J. Ilmu Komput. dan Agri-Informatika, vol. 2, no. 2, p. 83, 2013.

[15] E. Susilo, B. Soedijono WA, and H. Al Fatta, "Evaluasi Aplikas Mobile SSP (Secure System Of Payment) Menggunakan Prinsip Usability," Semin. Nas. Teknol. Inf. dan Multimed. 2017, vol. 2.6, pp. 7-12, 2017. 